\title{
Interferensi Sintaksis Bahasa Indonesia pada Keterampilan Berbicara Bahasa Inggris Mahasiswa Non-Jurusan Bahasa Inggris
}

\author{
${ }^{1}$ Amir hamzah, ${ }^{2}$ Muhamad Taufik Hidayat, ${ }^{3}$ Wahid Hasyim \\ ${ }^{1,2,3}$ Prodi Pendidikan Bahasa Inggris, Institut Pendidikan Indonesia \\ Jl. Pahlawan No. 32, Garut 44151, Jawa Barat, Indonesia \\ 1amirhamzah@institutpendidikan.ac.id, \\ ${ }^{2}$ mtaufikhidayat637@gmail.com, \\ 33ahidhasim2807@gmail.com
}

\begin{abstract}
This study aims to analyze the Indonesian language syntactic interference on English Speaking Skills of English Language Students. The research subjects were students of semester 3 at a non-English language college in Garut. This study uses a qualitative descriptive approach with equivalent and distribution methods. Meanwhile, the corpus was obtained by using the listening technique (SBLC), recording and taking notes from students' conversation assignments about their past activities in the form of videos. The results showed that the syntactic interference in this study includes the inaccuracy of word forms that are influenced by the past, inaccurate subject-verb agreements, inaccuracies, absence of articles, sentence patterns that do not match $S+V+O$, inaccurate use of the words 'no' and 'not'.
\end{abstract}

Keywords: interference, syntax, speaking skills

\begin{abstract}
ABSTRAK
Penelitian ini bertujuan menganalisis interferensi sintaksis bahasa Indonesia pada Keterampilan Berbicara Bahasa Inggris (English Speaking Skill) Mahasiswa Non-Jurusan Bahasa Inggris. Subjek penelitian adalah mahasiswa semester 3 tingkat 2 di salah satu perguruan tinggi non-jurusan bahasa Inggris di Garut. Penelitian ini menggunakan pendekatan deskriptif kualitatif dengan metode padan dan distribusional. Sementara, korpus diperoleh dengan teknik simak (SBLC), rekam dan catat dari tugas percakapan mahasiswa tentang kegiatan masa lampau mereka dalam bentuk video. Hasil menunjukkan bahwa interferensi sintaksis pada penelitian ini meliputi ketidaktepatan bentuk kata yang dipengaruhi kala lampau, ketidaktepatan subject-verb agreement, ketidakparalelan, ketidakhadiran artikel, Pola kalimat yang tidak sesuai $\mathrm{S}+\mathrm{P}+\mathrm{O}$, ketidaktepatan penggunaan kata 'no' dan 'not'.
\end{abstract}

Kata Kunci: interferensi, analisis kesalahan, keterampilan berbicara 


\section{PENDAHULUAN}

Seperti kita ketahui bahwa bahasa Inggris adalah bahasa internasional yang banyak digunakan di berbagai tempat dan untuk berbagai tujuan sebagai sebuah lingua franca. Bahasa Inggris bagi beberapa penutur merupakan sebuah bahasa ibu, bagi penutur lainnya merupakan sebuah bahasa kedua, dan masih bagi penutur lainnya lagi bahasa Inggris merupakan sebuah bahasa asing (Wardhaugh, 2006).

Di Indonesia bahasa Inggris merupakan bahasa asing yang peranannya sangat krusial sehingga para pengambil kebijakan mewajibkan kepada para peserta didik -dari sekolah dasar sampai perguruan tinggi -untuk menguasai bahasa Inggris hingga berpeluang besar dijadikan sebagai bahasa pengantar pendidikan di beberapa sekolah atau perguruan tinggi yang ada di Indonesia. Saukah (2003) mengungkapkan bahwa fungsi pengajaran bahasa Inggris di Indonesia dalam konteks globalisasi tidak akan banyak berubah, yaitu sebagai alat yang sangat diperlukan untuk penyerapan ilmu dan teknologi, serta untuk berkomunikasi dengan bangsa lain dalam kerangka hubungan internasional di berbagai aspek kehidupan manusia.

Seiring dengan perkembangan teknologi dan zaman, peserta didik dituntut mempelajari bahasa Inggris sehingga dapat bersaing dengan negara lain di era yang makin canggih ini. Di era tersebut, semua orang dituntut dapat menguasai IPTEK, penuh dengan suasana kompetitif dalam berbagai bidang (Agustin, 2011) karena bahasa Inggris merupakan salah satu kunci untuk membuka pintu-pintu terhadap ilmu pengetahuan.

Di level pendidikan tinggi, seluruh program studi memberikan mata kuliah Bahasa Inggris untuk 1 atau 2 semester meskipun disiplin ilmu yang diambil tidak berkaitan dengan Bahasa Inggris (Megawati, 2016). Namun, sengaja ataupun tidak sengaja seringkali terjadi interferensi ketika mahasiswa menggunakan bahasa Inggris. Hal ini disebabkan karena banyaknya perbedaan dan persamaan antara bahasa keseharian mereka dengan bahasa Inggris yang sedang dipelajari (Natsir \& Rahmawati, 2018). Berikut contoh bentuk Interferensi sintaksis sederhana yang sering dilakukan oleh mahasiswa dalam proses pembelajaran keterampilan berbicara (percakapan) bahasa Inggris:

\section{T: How did you get there? \\ $S:$ Can get there by riding my private vehicle}

Pada contoh diatas, Student (mahasiswa) cenderung mentransfer bentuk, makna dan budaya bahasa bahasa Indonesia ke bahasa dan budaya bahasa bahas Inggris. Dengan mempelajari kebiasaan bahasa Inggris, kebiasaan bahasa Indonesia juga ditransfer dan kemudian terjadi interferensi. Oleh karena itu, penelitian ini bertujuan untuk mengetahui, menganalisis mendeskripsikan dan membahas interferensi sintaksis bahasa Indonesia pada Keterampilan Berbicara Bahasa Inggris (English Speaking Skill) Mahasiswa Non-Jurusan Bahasa Inggris.

\section{KAJIAN PUSTAKA}

Dengan bahasa, seseorang dapat menyampaikan ide, pikiran, perasaan atau informasi kepada orang lain, baik secara lisan maupun tulisan (Yule, 2010) karena Bahasa merupakan alat komunikasi dan interaksi (Alwasilah A. C., 1993) dalam kehidupan sehari-hari. Kedua hal tersebut -lisan dan tulisan -merupakan keterampilan produktif (productive skills) dalam 
berbahasa (Brown H. D., 2001) dan keterampilan encoding (encoding skill) (Broughton, Brumfit, Flavell, Hill, \& Pincas, 1980).

Bahasa Inggris, seperti bahasa lainnya, memiliki aturan gramatikal. Karakteristik bahasa Inggris memiliki sifat inflektif yang sangat dipengaruhi oleh kala (tense) dalam penggunaan verbanya. Hal ini berbeda dengan bahasa Indonesia yang aglutinatif -tidak mengenal kala (Budiarti, 2013). Oleh karena itu, pada praktiknya interferensi bahasa merupakan salah satu masalah saat ini dalam pengajaran bahasa asing.

Dari sudut pandang linguistik, Menurut Weinreich, interferensi merupakan perubahan suatu sistem bahasa sehubungan dengan adanya persentuhan bahasa tersebut dengan unsurunsur bahasa lain yang dilakukan oleh penutur yang bilingual (dalam Chaer dan Agustina, 1995:159). Hal senada juga diungkapkan bahwa interferensi adalah interaksi atau perubahan struktur linguistik dan elemen struktur. Tampaknya merupakan penyimpangan dari norma linguistik dalam bahasa lisan dan tulisan (Lekova, 2010).

Interferensi bahasa dalam berkomunikasi lisan dan tulisan tidak bisa dihindari dalam komunikasi pembelajar yang berlatarbelakang budaya dan bahasa Indonesia dan Sunda ketika mereka menggunakan (berbicara) bahasa Inggris. Pembelajar bahasa asing (baca bahasa Inggris) cenderung mentransfer bentuk, makna dan budaya bahasa L1 (baca bahasa Indonesia) mereka ke bahasa dan budaya asing ketika mencoba untuk berbicara bahasa tersebut. Dengan mempelajari kebiasaan bahasa asing, kebiasaan bahasa L1 juga ditransfer dan kemudian terjadi kesalahan (Beebe \& Seliger, Nemati \& Taghizadeh, seperti dikutip dalam Derakhshan \& Karimi, 2015). Demikian pula Beardsmore mengemukakan bahwa jika pembelajar mengalami kesulitan dalam fonologi, kosakata dan tata bahasa bahasa asing, hal ini disebabkan adanya gangguan kebiasaan dari L1 (Derakhshan \& Karimi, 2015).

Berbagai penelitian empiris menunjukkan bahwa interferensi akan selalu ada sebagai salah satu penyebab kesalahan para pembelajar bahasa meski dengan presentase yang berbeda-beda. Bahkan secara lebih ekstrim, para pendukung analisis kontrastif mengatakan bahwa interferensi adalah satu-satunya sumber munculnya kesalahan-kesalahan dalam berbahasa Asing (Abd Chaer, 2009: 3).

\section{Metode Penelitian}

Penelitian ini menggunakan pendekatan deskriptif kualitatif dengan metode padan dan distribusional. Subjek penelitian adalah mahasiswa semester 3 tingkat 2 di salah satu perguruan tinggi non-jurusan bahasa Inggris di Garut. Jumlah keseluruhan mahasiswa adalah 87, peneliti hanya mengambil sampel sejumlah 35 mahasiswa.

Korpus diperoleh dengan teknik simak (SBLC), rekam dan catat dari tugas percakapan mahasiswa tentang kegiatan masa lampau mereka. Percakapan tersebut direkam dalam bentuk video. Dalam penggunaan teknik SBLC peneliti tidak terlibat dalam dialog, konversi, atau imbal wicara. Peneliti tidak ikut serta dalam proses pembicaraan subjek yang saling berbicara. Peneliti hanya sebagai pemerhati yang dengan penuh tekun mendengarkan apa yang dikatakan oleh subjek (Sudaryanto, 1993). Istilah simak tidak hanya berkaitan dengan penggunaan bahasa lisan, tetapi juga berkaitan dengan pengunaan bahasa tulis, yaitu mengamati, membaca, dan memahami bahasa tulis yang ada di dalam suatu teks tertulis ( (Zaim, 2014). Dengan demikian, pencatatan dilakukan pada kartu data (corpus) yang sesuai dengan objek penelitian. 
Analisis data dilakukan setelah data yang relevan dengan masalah penelitian terkumpul dan dicatat melalui sistem pengartuan. Data tersebut disusun secara sistematis, diorganisasikan ke dalam kategori, dijabarkan ke dalam unit-unit, dilakukan sintesa, disusun ke dalam pola, dipilih mana yang penting danyang akan dipelajari, dan dibuatkan kesimpulan (Sugiyono, 2013).

Analisis ini menggunakan metode distribusional yang mencoba menganalisis satuan lingual bahasa dalam hubungannya dengan satuan lingual lainnya. Teknik analisis yang digunakan berupa penguraian satuan lingual tertentu atas unsur-unsur terkecilnya, unsur langsungnya, penggantian suatu unsur oleh unsur lain dalam suatu konteks tertentu, perluasan, penghilangan satuan lingual, dan penyisipan suatu satuan lingual tertentu (Zaim, 2014).

Teknik yang digunakan dalam metode distribusional pada penelitian ini adalah teknik hubung banding membedakan (HBB). Teknik ini dilakukan dengan menghubungkan dan membandingkan perbedaan-perbedaan struktur atau kaidah bahasa Indonesia dan bahasa Inggris sehingga dapat diketahui interferensi yang terjadi. Langkah-langkah yang ditempuh dalam melakukan teknik tersebut adalah (1) mengidentifikasi data hasil keterampilan berbicara mahasiswa yang di dalamnya terjadi inteferensi; (2) mengklasifikasikan bentukbentuk interferensi sintaksis; (3) membandingkan struktur atau kaidah bahasa Indonesia dan bahasa Inggris pada data yang di dalamnya terdapat interferensi; (4) menginterpretasi penyebab terjadinya interferensi dan mendeskripsikannya (Hidayat \& Setiawan, 2015).

\section{HASIL DAN PEMBAHASAN}

Berdasarkan hasil analisis, interferensi sintaksis pada penelitian ini meliputi ketidaktepatan bentuk kata yang dipengaruhi kala lampau, ketidaktepatan subject-verb agreement, ketidakparalelan, ketidakhadiran artikel, Pola kalimat yang tidak sesuai $\mathrm{S}+\mathrm{P}+$ O, ketidaktepatan penggunaan kata 'no' dan 'not'.

\section{Ketidaktepatan bentuk kata yang dipengaruhi kala lampau \\ [1] I ride a motorcycle}

Korpus [1] merupakan jawaban dari pertanyaan "How did you get there?" Interferensi sintaksi dari korpus tersebut adalah ketidaktepatan bentuk kata kerja yang dipengaruhi kala lampau. Pertanyaan dari jawaban yang mengalami interferensi diatas merupakan bentuk simple past dalam bahasa Inggris. Dengan demikian, jawaban dari pertanyaan tersebut seharusnya "I rode a motorcycle" karena rode merupakan bentuk verba lampau irregular dari ride.

[2] It only takes about 2 hours

Korpus [2] merupakan jawaban dari pertanyaan "How long did it take to get there?" Interferensi sintaksi dari korpus tersebut adalah ketidaktepatan bentuk kata kerja yang dipengaruhi kala lampau. Pertanyaan dari jawaban yang mengalami interferensi diatas merupakan bentuk simple past dalam bahasa Inggris. Dengan demikian, jawaban dari pertanyaan tersebut seharusnya "It only took about 2 hours" karena took merupakan bentuk verba lampau irregular dari take.

Interferensi sintaksis terjadi karena terdapat perbedaan pola susunan kalimat bahasa Indonesia dengan bahasa Inggris yang memiliki kala/tense. Kala/tense menimbulkan perubahan pada verba dan kata kerja bantu/to be dalam pembentukan kalimat bahasa Inggris seperti pada kalimat "I went to Bandung yesterday", sedangkan dalam bahasa Indonesia, 
tidak ada kala/tenses, sehingga dalam pola kalimat bahasa Indonesia tidak terjadi perubahan verba tetapi kala/tense ditunjukkan dengan kata keterangan/adverbial kala, misalnya: "Saya pergi ke Bandung kemarin."

Tabel. 1 Ketidaktepatan bentuk kata yang dipengaruhi kala lampau

\begin{tabular}{|c|c|}
\hline Korpus & Seharusnya \\
\hline $\begin{array}{l}\text { Q: When were you born? } \\
\text { [3] I born October 31th, } 1997\end{array}$ & I was born on October 31 $1^{\text {st }} 1997$ \\
\hline $\begin{array}{l}\text { Q: How many days was your vacation? } \\
\text { [4] I spend two days enjoying the Bandung } \\
\text { [5] My vacation for three days }\end{array}$ & $\begin{array}{l}\text { I spent two days in Bandung } \\
\text { My vacation was three days }\end{array}$ \\
\hline $\begin{array}{l}\text { Q: Where did you go for your last vacation? } \\
\text { [6] I did went to kamojang }\end{array}$ & I went to Kamojang \\
\hline $\begin{array}{l}\text { [7] There were many activities we can do there, } \\
\text { for example eating, taking a picture, shopping } \\
\text { and many more }\end{array}$ & $\begin{array}{l}\text { There were many activities we could do } \\
\text { there, for example eating, taking a picture, } \\
\text { shopping and many more }\end{array}$ \\
\hline
\end{tabular}

\section{Ketidakparalelan}

[8] I did many things, such as playing with my family, saw beautiful view, and taking a picture

[9] There we took a walk, shopping, playing at the beach and hang out on the curb while playing music

Ketidakparalelan pada korpus [8] dapat diperbaiki dengan mengganti kata saw (verba lampau) menjadi seeing (gerund). Sementara korpus [9] bisa diperbaiki dengan mengganti kata shopping menjadi shopped, kata playing menjadi played dan hang menjadi hanged.

\section{Ketidakhadiran artikel}

[10] I didn't stay at hotel

[11] I didn't buy souvenir

Dalam bahasa Inggris, artikel a/an digunakan sebelum nomina (kata benda) tunggal yang dapat dihitung. artikel a/an ini bemakna satu, sebuah, atau suatu. Sementara, nomina jamak yang dapat dihitung tidak menggunakan a/an. Dengan demikian, korpus [10] dapat diperbaiki dengan menambah artikel a/an pada nominanya, menjadi "I didn't stay at a hotel" dan korpus [11] menjadi "I didn't buy a souvenirs." Korpus [10] dan [11] terjadi interferensi bahasa Indonesia ke dalam bahasa Inggris karena artikel a/an yang sepadan dengan satu/sebuah jarang digunakan dalam bahasa Indonesia, misalnya: "Saya menginap di sebuah hotel,"

\section{Pola kalimat yang tidak sesuai $\mathbf{S}+\mathbf{P}+\mathbf{O}$}

[12] Time it takes three hours

[13] Time to get there is three hours

Bahasa Indonesia dan bahasa Inggris memiliki persamaan dalam pola susun kata, yaitu S-V-O. Namun, kedua bahasa tersebut memiliki pula perbedaan-perbedaan kaidah yang dapat menyebabkan interferensi. Korpus [12] "Time it takes three hours" yang merupakan jawaban dari pertanyaan "How long did it take to get there?"terjadi interferensi pada salah satu pola 
susun kalimat, yakni Subjek. Korpus tersebut memiliki dua kata untuk subjek secara bersamaan dalam satu kalimat (Time dan It). korpus [12] dapat diperbaiki dengan menghilangkan kata Time sehingga menjadi "It takes three hours". Namun, dari segi tense (kala), kalimat tersebut masih terjadi kesalahan. Kalimat tersebut dapat diganti dengan simple past, "It took three hours".

Korpus [13] Time to get there is three hours yang merupakan jawaban yang sama dari pertanyaan seperti korpus [12] juga memiliki interferensi bahasa Indonesia. Dari segi pola SV-O, kalimat tersebut dikatakan benar karena Time to get there merupakan subjek, is sebagai verba, dan three hours sebagai complement. Namun, kalimat/ungkapan yang benar untuk jawaban pertanyaan "How long did it take to get there?" adalah "It took three hours to get there".

\section{Ketidaktepatan penggunaan kata ' $n o$ ' dan ' $n o t$ '}

[14] Not

[15] There is no

Korpus [14] Not yang merupakan jawaban dari pertanyaan Did you have a part-time job during the holidays? memiliki interferensi. Untuk menjawab pertanyaan negatif saja cukup dengan kata No bukan Not. Sementara, korpus [15] juga terjadi interferensi. Untuk menjawab pertanyaan tersebut, kita bisa menjawabnya dengan satu kata ("No"), atau lebih (No, I didn't. atau No, I didn't have a part-time job during the holidays.)

\section{KESIMPULAN DAN SARAN}

Interferensi merupakan kendala yang dihadapi oleh pembelajar bahasa asing (bahasa Inggris). Dominasi bahasa Indonesia berpengaruh besar terhadap keterampilan berbahasa Inggris. Munculnya interferensi ini disebabkan oleh rendanya kemampuan gramatikal, khususnya sintaksis, sehingga unsur-unsur dan pola bahasa Indonesia mendominasi bahasa Inggris tanpa disadari. Akibatnya, hal tersebut merusak tatanan struktur bahasa Inggris yang baik dan benar secara kaidah (Nashoih, 2019).

Bahasa Indonesia dan bahasa Inggris memiliki persamaan dalam pola susun kata, yaitu $\mathrm{S}-\mathrm{V}-\mathrm{O}$. Namun, kedua bahasa tersebut memiliki pula perbedaan-perbedaan kaidah yang dapat menyebabkan interferensi. Bedasarkan penelitian dan pembahasan hasil penelitian, maka dapat disimpulkan bahwa interferensi sintaksis bahasa Indonesia ke dalam bahasa Inggris pada keterampilan berbicara bahasa Inggris dengan tema kegiatan di masa lampau terjadi dalam pola susun frasa dalam kalimat. Identifikasi ciri tersebut dapat dilihat dari ketidaktepatan bentuk kata yang dipengaruhi kala lampau, ketidaktepatan subject-verb agreement, ketidakparalelan, ketidakhadiran artikel, ketidaktepatan penggunaan kata ' $n o$ ' dan 'not'. Hal ini disebabkan karena perbedaan pola susun frasa dan kalimat pada kedua bahasa tersebut.

Satu-satunya cara pelajar dapat mulai berkomunikasi dalam bahasa kedua adalah saat pelajar mulai mengasumsikan persamaan terjemahan kata demi kata atau diperkirakan bahwa setiap kata L1(baca bahasa Indonesia) memiliki satu terjemahan dalam L2 (baca bahasa Inggris) oleh pelajar. Dengan demikian, bentuk-bentuk interferensi sintaksis bahasa Indonesia pada keterampilan berbicara bahasa Inggris terjadi pada problem tenses dan problem kesesuaian susunan yang meliputi: bentuk tunggal dan jamak (nominal). Faktor penyebab munculnya interferensi tersebut karena dan minimnya pengetahuan tentang kaidah bahasa bahasa Inggris. Pembelajar harus menguasai kaidah-kaidah atau aturan-aturan kebahasaan, 
serta harus mampu menggunakannya dalam berbagai kegiatan sehari-hari. Kebiasaan berbicara tidak dapat dicapai tanpa kebiasaan berinteraksi dalam bahasa yang dipelajari atau bahkan bahasa ibu (Iskandarwassid \& Sunendar, 2011)

\section{DAFTAR PUSTAKA}

[1] R. Wardhaugh, An Introduction to Sociolinguistics (fifth edition), United Kingdom: Blackwell Publishing, 2006.

[2] Y. Agustin, "Kedudukan Bahasa Inggris sebagai Bahasa Pengantar dalam Dunia Pendidikan," Deiksis, pp. 354-364, 2011.

[3] F. Megawati, "KESULITAN MAHASISWA DALAM MENCAPAI PEMBELAJARAN BAHASA INGGRIS SECARA EFEKTIF," JURNAL PEDAGOGIA, pp. 147-156, 2016.

[4] M. Natsir dan A. Rahmawati, "BENTUK INTERFERENSI SINTAKSIS BAHASA INDONESIA DALAM BERBAHASA ARAB,” IJAZ ARABI, pp. 122-129, 2018.

[5] G. Yule, The Study of Language, New York: Cambridge University Press, 2010.

[6] A. C. Alwasilah, Linguistik: Suatu Pengantar, Bandung: Penerbit Angkasa, 1993.

[7] H. D. Brown, Teaching by Principles: An Interactive Approach to Language Pedagogy (Second Edition), New York: Pearson ESL, 2001.

[8] G. Broughton, C. Brumfit, R. Flavell, P. Hill dan A. Pincas, Teaching English as A Foreign language (Second Edition), New York: Routledge, 1980.

[9] A. Budiarti, "Interferensi bahasa Indonesia ke dalam bahasa Inggris pada abstrak jurnal ilmiah."," Bahasa Dan Seni: Jurnal Bahasa, Sastra, Seni, dan Pengajarannya, p. 41.1, 2013.

[10] B. H. Lekova, "LANGUAGE INTERFERENCE AND METHODS OF ITS OVERCOMING IN FOREIGN LANGUAGE TEACHING," Trakia Journal of Sciences, pp. 320-324, 2010.

[11] A. Derakhshan dan E. Karimi, "The Interference of First Language and Second Language Acquisition," Theory and Practice in Language Studies, pp. 2112-2117, 2015.

[12] Sudaryanto, Metode dan aneka teknik analisis bahasa, Yogyakarta: Duta Wacana University Press, 1993.

[13] M. Zaim, Metode Penelitian Bahasa: Pendekatan Struktural, Padang: Sukabina Press Padang, 2014.

[14] Sugiyono, Metode Penelitian Pendidikan: Pendekatan Kuantitatif, Kualitatif dan R \& D, Bandung: Penerbit Alfabeta, 2013.

[15] R. Hidayat dan T. Setiawan, "INTERFERENSI BAHASA JAWA KE DALAM BAHASA INDONESIA PADA KETERAMPILAN BERBICARA SISWA NEGERI 1 PLERET, BANTUL," LingTera, pp. 156 - 168, 2015.

[16] A. K. Nashoih, "POLA INTERFERENSI SINTAKSIS BAHASA INDONESIA DALAM BAHASA ARAB PADA INSYA' MAHASISWA PENDIDIKAN BAHASA ARA," dalam Konferensi Nasional bahasa Arab V, Malang, 2019.

[17] Iskandarwassid dan D. Sunendar, Strategi Pembelajaran Bahasa, Bandung: PT Remaja Rosdakarya, 2011.

[18] Iskandarwassid dan D. Sunendar, Strategi Pembelajaran Bahasa, bandung: PT Remaja Rosdakarya, 2011.

[19] A. C. Alwasilah, Linguistik: Suatu Pengantar, Bandung: Penerbit Angkasa, 1993. 
[20] "ilmubahasa.net," 06 OKTOBER 2016. [Online]. Available: https://www.ilmubahasa.net/2016/10/metode-simak-dan-tenik-tekniknya.html. [Diakses 09 December 2020].

[21] A. Saukah, ""Pengajaran bahasa Inggris di Indonesia: Tinjauan terhadap unjuk kerja pembelajar serta upaya peningkatannya."," 03 March 2003. [Online]. Available: http://library.um.ac.id/index.php/Pidato-Pengukuhan-Guru-Besar/pengajaran-bahasainggris-di-indonesia-tinjauan-terhadap-unjuk-kerja-pembelajar-serta-upayapeningkatannya.html. [Diakses 09 December 2020].

[22] H. D. Brown, Teaching by Principles: An Interactive Approach Language Pedagogy, New Jersey: Prentice-Hall, Inc., 1994.

[23] A. Chaer dan L. Agustina, Sosiolinguistik: Suatu Pengantar, Jakarta: Rineka Cipta, 1995. 